\title{
Analisis Pengaruh Kualitas Produk dan Kualitas Layanan terhadap Kepuasan Pelanggan Pasar Bisnis (Studi pada CV Kreasindo Mitra Pratama)
}

\author{
Heri Siswanto $^{1)}$, Fitroh Adhilla ${ }^{2)}$, Purwoko $^{3)}$ \\ 1), 2), 3) Program Studi S2 Manajemen, Universitas Ahmad Dahlan, Yogyakarta \\ Email: siswantoheri.uad@yahoo.com ${ }^{l}$, fitroh.adhilla@mgm.uad.ac.id ${ }^{2}$, purwokopurwo@yahoo.co.id ${ }^{3)}$
}

\begin{abstract}
ABSTRAK
Tujuan penelitian ini untuk menguji pengaruh kualitas produk dan kualitas layanan terhadap kepuasan konsumen pada pasar bisnis. Jenis penelitian ini menggunakan metode kuantitatif. Jumlah populasi sebanyak 70 pelanggan institusi yang sudah melakukan transaksi minimal dua kali di CV Kreasindo Mitra Pratama. Teknik pengambilan sampel menggunakan sampling jenuh. Teknik analisis data menggunakan regresi linier berganda dengan menggunakan program IBM SPSS 17. Hasil penelitian menunjukkan bahwa kualitas produk dan kualitas layanan secara simultan mempunyai pengaruh positif dan signifikan terhadap kepuasan konsumen. Hal ini dikarenakan nilai signifikansi dalam uji $F$ adalah sebesar 0,000 lebih kecil dari alpha 0,05. Sedangkan secara parsial variabel kualitas produk berpengaruh terhadap kepuasan pelanggan dengan nilai $t$ hitung sebesar 2,306 dan signifikansi 0,026. Variabel penampilan fisik tidak berpengaruh terhadap kepuasan pelanggan dengan nilai t hitung sebesar-1,261 dengan signifikansi 0,214. Variabel keterandalan tidak berpengaruh terhadap kepuasan pelanggan dengan nilai t hitung sebesar -0, 539 dengan signifikansi 0,659. Variabel daya tanggap berpengaruh terhadap kepuasan pelanggan dengan nilai $t$ hitung sebesar 3,071 dengan signifikansi 0,004. Variabel jaminan tidak berpengaruh terhadap kepuasan pelanggan dengan nilai t hitung sebesar 1,083 dengan signifikansi 0,285. Variabel empati mempunyai nilai $t$-0,811 tidak berpengaruh terhadap kepuasan pelanggan dengan nilai signifikansi sebesar 0,422.
\end{abstract}

Kata Kunci: Kualitas Produk, Kualitas Layanan, Keterandalan, Daya Tanggap, Kepuasan Pelanggan

\section{Pendahuluan}

Faktor pelayanan untuk memuaskan pelanggan merupakan hal yang sangat penting bagi setiap usaha. Pelanggan merupakan aset yang harus dipertahankan dalam perusahaan. Suatu perusahaan tidak akan bisa menjual produk atau jasa secara berkelanjutan jika tanpa pelanggan dan cepat atau lambat akan mengalami kegagalan. Secara umum pelanggan lebih menyukai perusahaan yang memberikan pelayanan yang baik serta menunjukkan kepedulian kepada pelanggannya.

Persaingan usaha yang ketat pada saat ini merupakan tantangan yang harus dihadapi oleh para pengusaha. Penentuan target pasar, segmentasi pasar serta posisi produk terhadap pesaing menjadi kewajiban yang harus ditetapkan dalam sebuah persaingan usaha. Segmen pasar yang berbeda memerlukan strategi pendekatan yang berbeda pula. Segmen pasar bisnis (Business to Business) berbeda dengan segmen pasar konsumen (Business to Customer) baik dari segi strategi bisnis, pemasaran hingga cara pengambilan keputusannya.

CV Kreasindo Mitra Pratama merupakan salah satu perusahaan yang mayoritas pelanggannya adalah institusi atau perusahaan. Data perusahaan mencatat dari 375 pelanggan yang ada di sistem keuangan hanya 50 pelanggan yang merupakan pelanggan individu atau personal, selebihnya merupakan pelanggan institusi atau perusahaan. Usaha yang dirintis tahun 2002 ini memiliki omset yang terus meningkat, pada tahun 2002 sampai dengan 2005 omset rata-rata perbulan sebesar Rp. 50.000.000,00. Pada saat ini (2019) omset rata-rata perusahaan sudah mencapai Rp. 500.000.000,00 per bulan. CV Kreasindo Mitra Pratama memproduksi berbagai macam produk berdasarkan pesanan seperti merchandise, kaos, tas, topi, seragam serta kebutuhan kantor lainnya.

Pemilihan pasar bisnis sebagai target pemasaran CV Kreasindo Mitra Pratama ditetapkan oleh pemilik sejak awal dimulainya usaha, hal ini tak lepas dari pengalaman yang diperoleh pemilik sebagai seorang marketing sebelum mendirikan sebuah usaha. Tempat produksi yang kurang representatif tidak menjadi suatu kendala bagi perkembangan usahanya, hal ini disiasati dengan cara memperkuat tim pemasaran dengan melakukan sistem jemput bola. Selain menitikberatkan pada kualitas layanan, CV Kreasindo Mitra Pratama juga memprioritaskan kualitas produk sebagai kekuatan dalam menghadapi persaingan. Secara umum perusahaan yang memberikan kualitas layanan yang baik disertai dengan kualitas produk yang baik akan cenderung diminati oleh para pelanggan. Pelayanan yang diterima pelanggan dapat dijadikan standar dalam menilai kinerja suatu perusahaan. Pelayanan yang dapat memuaskan pelanggan menjadi penentu keberhasilan suatu perusahaan.

Menurut teorinya Parasuraman, dkk. (1988), mengukur kualitas layanan berdasarkan lima dimensi, yaitu: tangible, reliability, responsiveness, assurance dan empathy. Berdasarkan teori tersebut beberapa penelitian empiris (Aprianto, 2016; Hildayanti, Marnisah, \& Dinata, 2018; Putera \& Wahyono, 2018; Yanti, Karim, \& Wadud, 2018; Kurniawan \& Hildayanti, 2019; Pribadi, 2020; Oktareza, Halin, \& Handayani, 2020) mendukung dan membuktikan bahwa kualitas pelayanan berpengaruh terhadap kepuasan pelanggan. Penelitian tersebut juga membuktikan bahwa terdapat hubungan yang signifikan 
antara kualitas pelayanan terhadap kepuasan pelanggan. Penelitian yang dilakukan oleh Kartikaningrum (2013) menunjukkan bahwa kualitas pelayanan berpengaruh terhadap kepuasan pelanggan. Pelanggan yang mendapatkan pelayanan yang baik dan merasa puas cenderung akan melakukan pembelian jenis produk dan jasa di tempat yang sama.

Untuk mengetahui faktor-faktor apa saja yang mempengaruhi kepuasan pelanggan pada pasar bisnis, perlu dilakukan penelitian yang terkait dengan beberapa hal tersebut. Salah satu cara untuk memperoleh gambaran mengenai kepuasan pelanggan dapat dilakukan dengan pengamatan tentang kekuatan dan kelemahan produk, cara penanganan layanan atas permintaan pelanggan, serta menjawab pertanyaan mengenai keluhan pelanggan. Untuk mengetahui seberapa besar tingkat kepuasan pelanggan dapat menggunakan informasi yang valid dari variabel bukti fisik, keandalan, daya tanggap, jaminan dan empati serta bagaimana pengaruh masing-masing variabel itu terhadap kepuasan pelanggan di CV Kreasindo Mitra Pratama. Tujuan penelitian ini adalah untuk menguji pengaruh kualitas produk dan kualitas layanan terhadap kepuasan konsumen pada pasar bisnis

\section{Metode Penelitian}

Penelitian ini menggunakan metode kuantitatif yaitu penelitian tentang data yang dikumpulkan dan dinyatakan dalam bentuk angka-angka. Obyek penelitian ini adalah kualitas produk dan kualitas layanan sebagai determinasi kepuasan pelanggan pada CV Kreasindo Mitra Pratama. Teknik pengumpulan data menggunakan kuesioner dengan skala liker 1 sampai 5. Teknik pengambilan sampel menggunakan metode Sampling jenuh. Jumlah populasi dalam penelitian ini sebanyak 70 institusi. Alat analisis data dilakukan menggunakan uji analisis regresi linear berganda.

\section{Hasil Penelitian dan Pembahasan Karakteristik Responden}

Tabel 1. Karakteristik Responden Berdasar Jenis Kelamin

\begin{tabular}{|l|l|l|l|}
\hline No & $\begin{array}{l}\text { Jenis } \\
\text { Kelamin }\end{array}$ & Jumlah & Persentase \\
\hline 1 & Pria & 28 & $53,8 \%$ \\
\hline 2 & Wanita & 24 & $46,2 \%$ \\
\hline
\end{tabular}

Sumber: Data Primer 2019

Dalam penelitian ini pengumpulan data primer menggunakan kuesioner dengan media Google formulir maupun kuesioner manual yang disebarkan kepada 70 pelanggan CV Kreasindo Mitra Pratama. Kuesioner manual yang disebar sebanyak 12, sedangkan yang melalui media google formulir dikirimkan melalui Whats App (WA) sebanyak 58 kontak. Dari 70 responden yang merespon kuesioner sebanyak 52 orang yang semuanya adalah pengambil keputusan dalam pembelian di institusinya masing-masing. Ada 18 responden yang tidak merespon pengisian kuesioner, hal ini dikarenakan ada sebagian yang tidak familier terhadap cara pengisian kuesioner melalui google formulir, serta ada yang memang tidak ada waktu untuk mengisi karena kesibukan pekerjaan.

Berdasarkan tabel 1 di atas diketahui bahwa dari total responden sejumlah 52 terdiri dari 28 pria $(53,8 \%)$ dan 24 wanita $(46,2 \%)$, jumlah responden pria lebih tinggi dibandingkan responden wanita.

Tabel 2. Karakteristik Responden Berdasar Jenis Intitusi

\begin{tabular}{|l|l|l|l|}
\hline No & Jenis Institusi & Jumlah & Persentase \\
\hline 1 & $\begin{array}{l}\text { Institusi } \\
\text { Pemerintah }\end{array}$ & 16 & $30,8 \%$ \\
\hline 2 & $\begin{array}{l}\text { Institusi Non } \\
\text { Swasta Na } \\
\text { Perbankan }\end{array}$ & 17 & $32,7 \%$ \\
\hline 3 & $\begin{array}{l}\text { Institusi } \\
\text { Perbankan }\end{array}$ & 11 & $21,2 \%$ \\
\hline 4 & $\begin{array}{l}\text { Institusi } \\
\text { Pendidikan }\end{array}$ & 8 & $15,3 \%$ \\
\hline
\end{tabular}

Sumber: Data Primer 2019

Tabel 2 di atas menunjukkan bahwa yang menjadi pelanggan CV Kreasindo Mitra Pratama paling banyak berasal dari institusi swasta non perbankan yaitu 17 responden atau sebesar $32,7 \%$ dan dari institusi pemerintahan adalah 16 responden atau sebesar 30,8\% sedangkan dari institusi perbankan sebanyak 11 responden atau sebesar 21,2 \% dan sisanya adalah institusi pendidikan yaitu 8 responden atau sebesar $15,3 \%$.

Tabel 3. Karakteristik Responden Berdasar Jabatan

\begin{tabular}{|l|l|l|l|}
\hline No & Jabatan & Jumlah & Persentase \\
\hline 1 & $\begin{array}{l}\text { Owner } \\
\text { (Pemilik) }\end{array}$ & 11 & $21,2 \%$ \\
\hline 2 & Direktur & 9 & $17,3 \%$ \\
\hline 3 & $\begin{array}{l}\text { Kepala } \\
\text { Bidang } \\
\text { Manajer }\end{array}$ & 22 & $42,3 \%$ \\
\hline 4 & Staf & 5 & $9,6 \%$ \\
\hline 5 & Reseller & 5 & $9,6 \%$ \\
\hline
\end{tabular}

Sumber: Data Primer 2019

Tabel 3 di atas menunjukkan bahwa pengambil keputusan belanja paling banyak dilakukan oleh kepala bidang atau setingkat manajer yaitu sebanyak 22 institusi atau sebesar $42,3 \%$, sedangkan keputusan pembelian yang dilakukan oleh pemilik usaha sebanyak 11 institusi atau sebesar 21,2\%, direktur sebanyak 9 institusi atau 17,3\%, staf sebanyak 5 institusi atau 9,6\%, dan reseller sebanyak 5 institusi atau 9,6\%. Dari data tersebut bisa dilihat bahwa target pemasaran produk CV Kreasindo Mitra Pratama adalah pengambil keputusan langsung dari suatu institusi.

\section{Uji Hipotesis}

Uji Koefisien Determinasi (Adjusted $R^{2}$ )

Besarnya koefisien diterminasi $\left(\mathrm{R}^{2}\right)$ dalam penelitian ini diperlihatkan pada tabel berikut: 
Tabel 4. Rangkuman Koefisien Diterminasi $\left(R^{2}\right)$ Kepuasan pelanggan Pada CV Kreasindo Mitra Pratama

\begin{tabular}{|l|c|c|c|}
\hline Variabel & $\begin{array}{l}\text { Korelasi } \\
(\mathrm{R})\end{array}$ & $\begin{array}{l}\text { Koefisien } \\
\text { Diterminasi } \\
\mathrm{R}^{2}\end{array}$ & $\begin{array}{l}\text { Adjusted } \\
\mathrm{R} \\
\text { Square }\end{array}$ \\
\hline $\begin{array}{l}\text { Kualitas Produk, } \\
\text { Penampilan }\end{array}$ & 0,762 & 0,581 & 0,525 \\
$\begin{array}{l}\text { Fisik, } \\
\text { Keterandalan, } \\
\text { Daya Tanggap, } \\
\text { Jaminan dan } \\
\text { Empati }\end{array}$ & & & \\
\hline
\end{tabular}

Sumber: Olah Data 2019

Koefisien diterminasi (Adjusted $\mathrm{R}^{2}$ ) digunakan untuk mengetahui persentase pengaruh variabel independen (kualitas produk, penampilan fisik, keterandalan, daya tanggap, jaminan dan empati) terhadap perubahan variabel dependen (kepuasan pelanggan). Hasil olah data menunjukkan bahwa besarnya nilai koefisien determinasi (Adjusted $\mathrm{R}^{2}$ ) adalah 0,525, artinya besarnya pengaruh variabel independen terhadap perubahan variabel dependen sebesar $52,5 \%$, sedangkan sisanya sebesar $(47,5 \%)$ dipengaruhi oleh faktor lain.

\section{Uji Signifikan Nilai $t$}

Perhitungan t-test dilakukan menggunakan uji independent t-test. Hasil uji t-test adalah sebagai berikut:

Tabel 5. Hasil uji t-test

\begin{tabular}{|l|c|c|c|}
\hline \multirow{2}{*}{ Model } & Koefisien & & \\
\cline { 2 - 2 } & $\mathrm{B}$ & $\mathrm{t}$ & Sig. \\
\hline $\begin{array}{l}\text { Kualitas } \\
\text { produk }\end{array}$ & 4,663 & 3,477 & 0,001 \\
\hline $\begin{array}{l}\text { Penampilan } \\
\text { fisik }\end{array}$ & $-0,142$ & $-1,261$ & 0,214 \\
\hline Keterandalan & $-0,078$ & $-0,539$ & 0,593 \\
\hline Daya tanggap & 0,562 & 3,071 & 0,004 \\
\hline Jaminan & 0,129 & 1,083 & 0,285 \\
\hline Empati & $-0,133$ & $-0,811$ & 0,422 \\
\hline
\end{tabular}

Sumber: Olah Data 2019

Berdasarkan tabel 5 dapat diketahui bahwa secara keseluruhan didapatkan nilai $t$ test 3,477 dengan signifikansi 0,001. Sedangkan secara parsial variabel kualitas produk mempunyai nilai $t$ 2,306 dengan signifikansi 0,026. Variabel penampilan fisik mempunyai nilai $\mathrm{t}-1,261$ dengan signifikansi 0,214. Variabel keterandalan mempunyai nilai $\mathrm{t}-0,539$ dengan signifikansi 0,6593. Variabel daya tanggap mempunyai nilai t 3,071 dengan signifikansi 0,004. Variabel jaminan mempunyai nilai t 1,083 dengan signifikansi 0,285. Variabel empati mempunyai nilai $\mathrm{t}-0,811$ dengan signifikansi 0,422 .

Hasil penelitian ini menunjukkan bahwa untuk variabel kualitas produk dan daya tanggap mempunyai nilai $\mathrm{p}$ lebih kecil dari 0,05 sehingga dapat disimpulkan bahwa variabel kualitas produk dan daya tanggap berpengaruh positif secara parsial terhadap perubahan kepuasan pelanggan. Sedangkan variabel yang lain yaitu penampilan fisik, keterandalan, jaminan dan empati tidak mempunyai pengaruh secara parsial terhadap perubahan kepuasan pelanggan karena mempunyai nilai signifikansi (p) lebih besar dari 0,05.

\section{Uji Simultan (Uji F)}

Uji Simultan digunakan untuk mengetahui pengaruh variable independen (kualitas produk, penampilan fisik, keterandalan, daya tanggap, jaminan dan empati) terhadap perubahan variabel dependen (kepuasan pelanggan) secara bersama-sama, Dalam melakukan Uji simultan (Uji F) menggunakan program IBM SPSS 17 seperti dibawah ini :

Tabel 6. Uji Simultan (Uji F) ANOVA

\begin{tabular}{|l|r|r|r|l|l|}
\hline Model & $\begin{array}{l}\text { Sum of } \\
\text { Squares }\end{array}$ & df & $\begin{array}{l}\text { Mean } \\
\text { Squares }\end{array}$ & F & Sig \\
\hline Regression & 36.577 & 6 & 6.096 & 10.390 & .000 \\
Residual & 26.404 & 45 & .587 & & \\
Total & 63.981 & 51 & & & \\
\hline
\end{tabular}

Sumber: Olah Data 2019

Berdasarkan hasil olah data Anova diatas diketahui bahwa nilai signifikansi (Sig) dalam uji $\mathrm{F}$ adalah sebesar 0,000 . Karena nilai signifikansi $0,000<0,05$ maka dalam Uji F dapat disimpulkan bahwa kualitas produk, penampilan fisik, keterandalan, daya tanggap, jaminan dan empati secara simultan bersama-sama berpengaruh terhadap kepuasan pelanggan.

\section{Pembahasan}

Pengaruh Kualitas Produk terhadap Kepuasan Pelanggan pada CV Kreasindo Mitra Pratama

Hasil uji hipotesis menunjukkan bahwa terdapat pengaruh kualitas produk terhadap kepuasan pelanggan, apabila kualitas produk dalam 1 kali produksi meningkat 1 satuan maka secara signifikan kepuasan pelanggan akan meningkat sebesar 0,229 satuan. Menurut Kotler dan Amstrong (2015) kualitas produk merupakan senjata strategis yang potensial untuk mengalahkan pesaing. Temuan ini sejalan dengan penelitian-penelitian sebelumnya (Aditia, Wadud, \& DP, 2020;

Jadi hanya perusahaan dengan kualitas produk paling baik yang akan tumbuh dengan pesat, dan dalam jangka panjang perusahaan tersebut akan lebih berhasil dari perusahaan yang lain.

Adanya pengaruh kualitas produk terhadap kepuasan pelanggan menunjukkan bahwa kualitas produk CV Kreasindo Mitra Pratama telah memenuhi harapan dari pelanggan. Keunggulan-keunggulan dari produk dapat diketahui oleh pelanggan dan bisa membuat pelanggan tertarik untuk mencoba dan kemudian akan mengambil keputusan untuk membeli suatu produk tersebut. 
Pengaruh Penampilan Fisik terhadap Kepuasan Pelanggan pada CV Kreasindo Mitra Pratama

Lupiyoadi (2013) mendefinisikan tangible atau bukti fisik sebagai kemampuan perusahaan dalam menunjukkan eksistensinya kepada pihak eksternal. Dimaksudkan bahwa penampilan dan kemampuan sarana dan prasarana fisik perusahaan dan keadaan lingkungan sekitarnya adalah bukti nyata dari pelayanan yang diberikan.

Hasil penelitian menunjukkan tidak ada pengaruh penampilan fisik terhadap kepuasan pelanggan di mana apabila penampilan fisik dalam 1 kali produksi meningkat 1 satuan maka kepuasan pelanggan akan menurun sebesar 0,142 satuan namun tidak signifikan. Peneltian ini menunjukkan bahwa penampilan fisik CV Kreasindo Mitra Pratama tidak berpengaruh terhadap kepuasan pelanggan. Hal ini dikarenakan mayoritas pelanggan $\mathrm{CV}$ Kreasindo Mitra Pratama tidak berinteraksi langsung dengan kantor, keputusan jual beli antara pelanggan dengan marketing biasanya dilakukan di kantor tempat pelanggan bekerja.

\section{Pengaruh Keterandalan terhadap Kepuasan Pelanggan pada CV Kreasindo Mitra Pratama}

Menurut Lupiyoadi (2013:216) keterandalan merupakan kemampuan perusahaan untuk memberikan pelayanan sesuai dengan yang dijanjikan secara akurat dan terpecaya. Kinerja harus sesuai dengan harapan pelanggan yang berarti ketepatan waktu, pelayanan yang sama untuk semua pelanggan tanpa kesalahan, sikap yang simpatik, dan dengan akurasi yang tinggi. Keterandalan adalah kemampuan perusahaan untuk memberikan pelayanan sesuai yang dijanjikan secara akurat dan terpercaya. Indikator pada variabel keterandalan ini meliputi: koordinasi karyawan di lingkungan internal, koordinasi karyawan dengan instansi teknis, penyelesaian proses pelayanan pelanggan sejak awal hingga akhir serta sikap profesional yang ditunjukkan karyawan.

Hasil penelitian ini menunjukkan tidak ada pengaruh dimensi keterandalan terhadap kepuasan pelanggan pada CV Kreasindo Mitra Pratama, apabila keterandalan dalam 1 kali produksi meningkat 1 satuan maka kepuasan pelanggan akan menurun 0,078 satuan namun tidak signifikan. Sebagaimana diketahui bahwa CV Kreasindo Mitra Pratama memproduksi barang berdasarkan pesanan dari pelanggan, terkadang pada saat yang bersamaan juga sedang mengerjakan pesanan dari pelanggan lain. Pada kondisi produksi sedang overload maka tidak menutup kemungkinan order pelanggan tidak bisa terlayani, sehingga untuk sementara pelanggan dengan terpaksa mengalihkan pesanannya ke tempat lain yang mungkin dengan standar kualitas berada dibawah produk CV Kreasindo Mitra Pratama dan berharap kedepan masih bisa memesan produk di CV Kreasindo Mitra Pratama.

Pengaruh Daya Tanggap terhadap Kepuasan Pelanggan pada CV Kreasindo Mitra Pratama

Daya tanggap adalah suatu kemauan untuk membantu dan memberikan pelayanan yang cepat dan tepat kepada pelanggan, dengan penyampaian informasi yang jelas. Variable daya tanggap ini meliputi hal-hal sebagai berikut: ketanggapan yang dimiliki karyawan bagian pelayanan, ketanggapan karyawan pelayanan dalam melayani keluhan-keluhan pelanggan.

Hasil penelitian menunjukkan ada pengaruh daya tanggap terhadap kepuasan pelanggan pada CV Kreasindo Mitra Pratama, apabila daya tanggap dalam 1 kali produksi meningkat 1 satuan maka secara signifikan kepuasan pelanggan akan meningkat sebesar 0,562. Sebagai perusahaan yang memiliki sistem pemasaran dengan melakukan jemput bola, CV Kreasindo Mitra Pratama selalu mengedepankan respon yang cepat terhadap pelanggan. Setiap ada informasi pelanggan akan melakukan order, bagian pemasaran dengan segera akan menindaklanjutinya. Pelanggan akan merasa puas dengan kualitas pelayanan daya tanggap staf CV Kreasindo Mitra Pratama yang mampu melayani pelanggan secara tepat, pelanggan memperoleh informasi yang detail berkaitan dengan berbagai informasi yang dibutuhkan perusahaan melalui karyawan, sangat cepat dalam menanggapi klaim dari para pelanggan serta staf perusahaan mampu memahami selera yang diinginkan oleh pelanggan.

\section{Pengaruh Jaminan terhadap Kepuasan Pelanggan pada} CV Kreasindo Mitra Pratama

Jaminan yaitu pengetahuan, kesopansantunan, dan kemampuan para pegawai perusahaan untuk menumbuhkan rasa percaya para pelanggan kepada perusahaan. Variabel ini meliputi hal-hal sebagai berikut: keramahan sikap para karyawan dalam melayani pelanggan, kejujuran sikap para karyawan dalam melayani pelanggan, pemahaman karyawan terhadap kebutuhan pelanggan, kemudahan dalam menghubungi para karyawan, pembagian kerja diantara karyawan.

Hasil penelitian menunjukkan tidak ada pengaruh jaminan terhadap kepuasan pelanggan pada CV Kreasindo Mitra Pratama, apabila jaminan dalam 1 kali produksi meningkat 1 satuan maka secara signifikan kepuasan pelanggan akan meningkat sebesar 0,129.

\section{Pengaruh Empati terhadap Kepuasan Pelanggan pada CV Kreasindo Mitra Pratama}

Empati adalah memberikan perhatian yang tulus dan bersifat individual atau pribadi kepada para pelanggan dengan berupaya memahami keinginan pelanggan. Kemampuan para karyawan untuk menumbuhkan rasa percaya para pelanggan dengan memberikan perhatian yang tulus dan berupaya memahami keinginan pelanggan. Sikap karyawan inilah yang menciptakan perilaku postif pelanggan. Hubungan empati dengan kepuasan pelanggan adalah apabila pelanggan telah merasa puas dengan empati yang diberikan perusahaan maka pelangganpun akan loyal dengan jasa atau produk yang diberikan perusahan tersebut (Kotler dan Keller, 2016).

Hasil penelitian menunjukkan tidak ada pengaruh empati terhadap kepuasan pelanggan pada CV Kreasindo Mitra Pratama, apabila empati dalam 1 kali produksi meningkat 1 satuan maka kepuasan pelanggan akan menurun 0,133 satuan namun tidak signifikan. 
Pengaruh Kualitas Produk dan Kualitas Layanan terhadap Kepuasan Pelanggan pada CV Kreasindo Mitra Pratama

Hasil penelitian ini menunjukkan bahwa secara simultan kualitas produk, penampilan fisik, keterandalan, daya tanggap, jaminan dan empati berpengaruh terhadap kepuasan pelanggan. Penelitian ini juga menghasilkan kesimpulan bahwa diantara keenam variable yang diuji tersebut yang memberikan pengaruh paling besar terhadap kepuasan pelanggan adalah daya tanggap dan kualitas produk. Hal tersebut dapat dijelaskan bahwa pelanggan akan merasa puas dengan kualitas pelayanan yang secara cepat direspon oleh bagian pemasaran. Kualitas produk ternyata menempati posisi kedua setelah daya tanggap yang mempengaruhi kepuasan pelanggan secara simultan.

Penelitian ini sesuai dengan penelitian yang dilakukan oleh penelitian sebelumnya (Triastity \& Triyaningsih, 2013; Amha, 2020) yang menunjukkan bahwa kepuasan pelanggan secara simultan dipengaruhi oleh dimensi-dimensi kualitas pelayanan jasa (penampilan fisik, keterandalan, daya tanggap, jaminan, dan empati). Temuan penelitian ini menunjukkan bahwa semakin tinggi tingkat kualitas layanan yang dipersepsikan, semakin besar kepuasan pelanggan. Hal ini disebabkan kualitas yang dipersepsikan pelanggan merupakan kemampuan memutuskan tentang kesempurnaan sebuah layanan atau suatu bentuk sikap dan evaluasi secara menyeluruh dalam jangka panjang.

\section{Kesimpulan}

Ada pengaruh kualitas produk terhadap kepuasan pelanggan pada CV Kreasindo Mitra Pratama. Tidak ada pengaruh penampilan fisik terhadap kepuasan pelanggan pada CV Kreasindo Mitra Pratama. Tidak ada pengaruh keterandalan terhadap kepuasan pelanggan pada CV Kreasindo Mitra Pratama. Ada pengaruh daya tanggap terhadap kepuasan pelanggan pada CV Kreasindo Mitra Pratama. Tidak ada pengaruh jaminan terhadap kepuasan pelanggan pada CV Kreasindo Mitra Pratama. Tidak ada pengaruh empati terhadap kepuasan pelanggan pada CV Kreasindo Mitra Pratama. Ada pengaruh kualitas produk dan kualitas layanan terhadap kepuasan pelanggan pada CV Kreasindo Mitra Pratama

\section{Daftar Pustaka}

Aditia, A. R. R., Wadud, M., \& DP, M. K. (2020). Pengaruh Kualitas Produk terhadap Kepuasan Konsumen Sepeda Motor NMAX pada PT Yamaha A. Rivai Palembang. Jurnal Nasional Manajemen Pemasaran \& SDM, 1(01), 23-37. https://doi.org/10.47747/jnmpsdm.v1i01.4

Amha, G. G. (2020). Determinants of Customer Satisfaction and Customer Loyalty in Amhara Credit and Saving Institute (ACSI): The Case of Waghimera Zone Sekota Town. International Journal of Marketing \& Human Resource Research, 1(01), 34-51. Retrieved from http://journal.jisinstitute.org/index.php/ijmhrr/article/view/70
Aprianto, R. (2016). Pengaruh Pelayanan Terhadap Kepuasan Nasabah Pada Kantor Pt Bank Bca Cabang Lubuklinggau. Jurnal Ilmiah Ekonomi Global Masa Kini, 7(1), 11-18.

Hildayanti, S. K., Marnisah, L., \& Dinata, E. S. (2018). Pengaruh Nilai, Kualitas Pelayanan dan Komitmen Organisasi Terhadap Kepuasan Pelanggan Pada PT. Asuransi Kresna Mitra Tbk Cabang Palembang. Jurnal Ilmiah Ekonomi Global Masa Kini, 9(1), 6170 .

Kartikaningrum, 2013, Pengaruh Tangible, Reliability, Responsiveness, Assurance,Empathy Terhadap Kepuasan Konsumen Waroeng Spesial Sambal (SS) Yogyakarta, Jurnal Manajemen Vol. 3 NO. 2 Desember 2013.

Kotler, Adam, Denize and Armstrong, 2015, Principles of marketing, 6e, Pearson Australia.

Kotler, Keller, 2016, Marketing Management 15th Edition, Pearson Education Limited.

Kurniawan, M., \& Hildayanti, S. K. (2019). Analisis Citra Merek, Harga, Pelayanan, dan Promosi terhadap Kepuasan Konsumen di Kota Palembang (Studi Kasus Konsumen Grab). Jurnal Ecoment Global, 4(2), 86-102.

Lupiyoadi, 2013, Manajemen Pemasaran Jasa Berbasis Kompetensi, Edisi ke 3 Salemba Empat, Jakarta.

Oktareza, M. E. T., Halin, H., \& Handayani, S. (2020). The Effect of Service on Customer Satisfaction at PT Pandu Siwi Sentosa. International Journal of Community Service \& Engagement, 1(01), 19-26. Retrieved from http://journal.jisinstitute.org/index.php/ijcse/article/view/74

Parasuraman, Zeithaml and Berry, 1988, "SERVQUAL: A Multiple Item Scale for Measuring Consumer Perceptions of Service Quality," Journal of Retailing, Vol 64 No 1.

Pribadi, G. (2020). Service Quality Sebagai Pengukuran Kepuasan Siswa dan Orang Tua/Wali Murid SMP Muhammadiyah 1 Gombong. Jurnal Ilmiah Ekonomi Global Masa Kini, 11(1).

Putra dan Wahyono, 2018, Pengaruh Kualitas Pelayanan, Citra Merek, dan Kualitas Produk terhadap Loyalitas Konsumen melalui Kepuasan Konsumen, Management Analysis Journal 7.

Triastity dan Triyaningsih, 2013, Pengaruh Tangible, Reliability, Responsiveness, Assurance dan Emphaty terhadap Kepuasan Konsumen (Survei Konsumen Rumah di CV Satria Graha Gedongan, Colomadu, Karanganyar) Jurnal Ekonomi dan Kewirausahaan Vol. 13 No. 2, Oktober 2013.

Yanti, F., Karim, A., \& Wadud, M. (2018). Pengaruh Kualitas Pelayanan Terhadap Kepuasan Konsumen Pada Studio Ribka Foto Cabang Sekip Di Palembang. Jurnal Ilmiah Ekonomi Global Masa Kini, 8(2), 47-52. 